\title{
Irrigation, gender, and social geographies of the changing waterscapes of southeastern Anatolia
}

\section{LEILA M. HARRIS}

Corresponding Author: Iharris@ires.ubc.ca

2006

Final version: Harris, L. (2006) Irrigation, Gender, and Social Geographies of the Changing Waterscape in Southeastern Anatolia. Environment and Planning D: Society and Space. 24

(2): 187-213. DOI: $10.1068 / \mathrm{d} 03 \mathrm{k}$ 
Table of Contents

SUMMARY

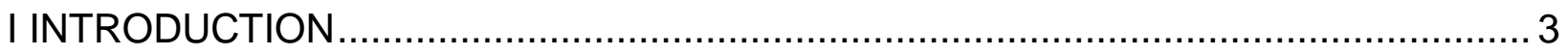

II CHANGING WATERSCAPES, SHIFTING SOCIAL GEOGRAPHIES ...................... 4

2.1. Changing uses of water: landlessness, livelihoods, and ethnicity ........................ 6

2.2. Management of water: water user groups and knowledge ............................. 10

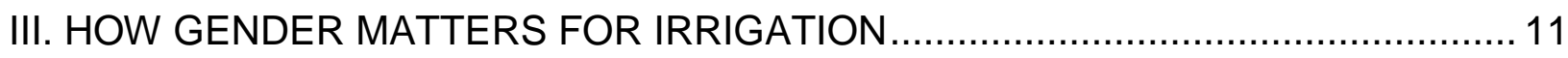

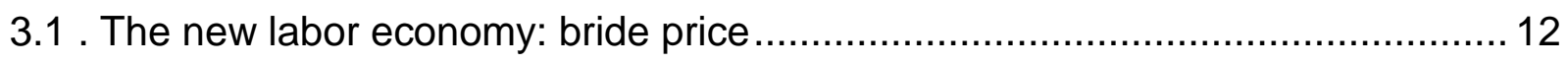

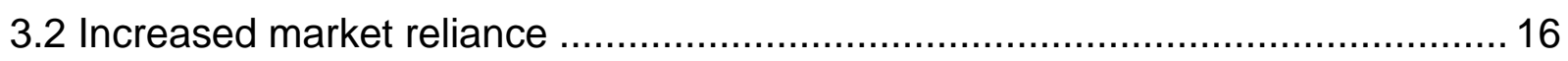

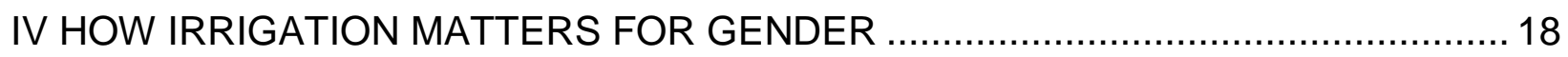

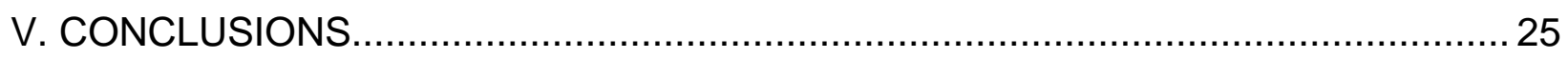

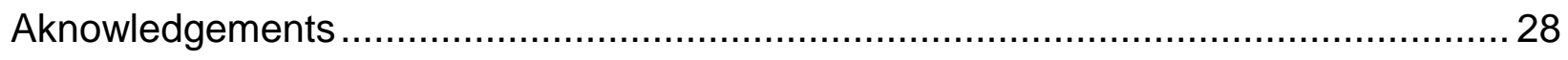

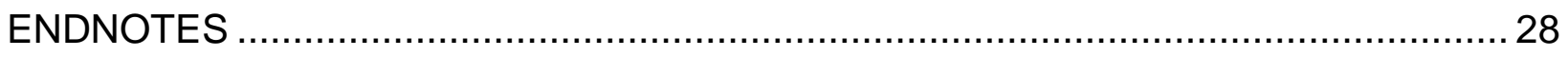

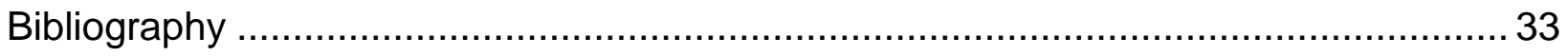




\section{SUMMARY}

Most theorists understand gender geographies as highly differentiated and shifting, in terms of both time and space. If gender is historically and geographically contingent then the analysis of gender should be attentive to the particular conditions that materialize the very idea of gender, giving it the appearance of being fixed and natural. The physical landscape, or waterscape in the case of southeastern Turkey, is potentially central to the ways that gender is invoked and lived in particular settings, with important effects. Using case-study work on irrigation-related changes in southeastern Turkey, I consider gender in relation to livelihoods and work practices, landholdings, and ethnicity revealing that, in addition to conditioning differential outcomes for residents of the plain, these categories of social difference are themselves fundamentally renegotiated and recast in relation to waterscape change. I argue that explicit consideration of environmental conditions and practices is central to understanding the operation of gender in certain contexts, as well as to understanding the lived experiences of women and men, providing insights for gender theory and politics.

Note: The information used in this paper is based primarily on fieldwork conducted in 2001 . The research involved government interviews and document review, open-ended interviews with farmers in the province of Şanl|urfa, and a survey of 125 households of the Harran plain conducted cooperatively with Professor Zuhal Karahan Kara of Harran University. Although Karahan Kara helped to administer the survey, she does not necessarily agree with the analysis presented here and in no way should be considered responsible for the content of this paper 


\section{INTRODUCTION}

A number of researchers have demonstrated that gender is critical for access to, use of, and management of resources (for example, Rocheleau et al, 1996; Schroeder, 1999), with implications for social status, household conflict, livelihoods, and well-being (see Agarwal, 1988; Carney, 1996; Carney and Watts, 1991). Among other issues, these works, as well as other detailed examinations from a variety of contexts have revealed the gender-differentiated effects of environmental changes, as well as the ways that household, conjugal, or gender relations may be renegotiated in light of changing environmental resource conditions or uses.

Evidence from southeastern Turkey similarly suggests that gender is central to differentiating outcomes of water-related changes for residents. The emphasis on gender in relation to nature-society relations developed in this paper builds on insights from these and other works, but also extends these discussions. Drawing on the case of large-scale developmental and environmental change in upper Mesopotamia, I argue that not only is gender central to conditioning resource access, management, or knowledges but, in turn, environmental considerations and outcomes are critical to conditioning the operations and understandings of gender. Other theorists have indicated that social interactions may shift in relation to environmental changes in important ways (for example, Carney, 1996; Katz, 1991; Schroeder, 1999). I endeavor here to detail similar linkages in the Turkish context, arguing that altered economies, labor practices, crops, and environmental conditions associated with the changing waterscape of the upper Tigris - Euphrates basin force renegotiations of men's and women's status and well-being(1) Extending these insights, I further argue that irrigation practices and differential water-resource geographies become central to defining and consolidating the very terms of difference in the region, be they associations with men and women, Kurd and Arab, or landed and landless.

The theorization engaged here favors an understanding of gender as the practices and processes through which notions of sex difference come to appear as natural and stable, though they are iteratively (re)produced and constantly shifting (Butler, 1993). This approach differs substantially from treatments which take gender to be defined as social relations that govern men's and women's differentiated knowledges of, or experiences of, environments (for example, Rocheleau et al, 1996). In the case of largescale waterscape change in southeastern Turkey, emergent irrigation ecologies and economies do result in differentiated outcomes for residents, but, as I detail here, these changes also serve to define and consolidate the very terms and parameters of social difference. Another dimension of the theorization of gender enlivened here relates to intersectionality. In the case of rural southeastern Turkey, gender, landholdings, ethnicity, and livelihoods are all interlinked processes of social difference and inequality that hold relevance for the social and political dimensions of water-related changes. Thus, although the analysis is clearly informed by critical work on gender, I seek to avoid privileging gender differences over other important inequalities. As such, I aim to contribute to a growing body of work that explicitly connects sex - gender to other processes and inequalities. 
In section 2 I introduce the dynamic setting of socioenvironmental change in the Harran plain of southeastern Turkey with particular attention to issues of landlessness, livelihoods, and ethnicity as critical factors that mediate differentiated effects of irrigation for residents of the plain. Attention to these issues helps to situate gender in relation to other critical social inequalities. In section 3 a discussion of changing labor demands of the new irrigated economy, related effects on the market for brides, and increased market reliance delineates ways that men and women are differentially situated with respect to ongoing environmental changes. This discussion provides evidence that gender is not only historically and geographically variable, but linked to specific practices and environmental conditions at different times and spaces. In section 4, I consider these results in conversation with theorizations of gender, demonstrating that gender is not only central for delineating differentiated outcomes of environmental changes, but also itself an effect of such changes. Tracing shifting associations and identities in relation to waterscape change, I consider both why gender matters for irrigation and changing waterscapes, and how, through the renegotiation of nature society relations, gender comes to matter at all.

\section{CHANGING WATERSCAPES, SHIFTING SOCIAL GEOGRAPHIES}

In the mid-1980s the Turkish government embarked on an aggressive development scheme seeking to utilize water resources of the Tigris and Euphrates rivers more effectively. Over the past few decades the state-led Southeastern Anatolia Project $(G A P)^{(2)}$ has evolved into what planners call an 'integrated regional-development project', including a diverse set of programs designed to maximize water efficiencies, promote economic development, and further social equity goals. In the most recent iterations of the project, extensive waterscape changes associated with the damming and diversion of the Tigris and Euphrates rivers have been recast as pivotal transformations that will eventually bring the Southeastern Anatolia region (figure 1) more in line developmentally with the rest of Turkey (Çarkoğlu and Eder, 1998; Harris, 2002). As it is one of the least economically developed regions of the country, and home to significant segments of Turkey's minority Kurdish and Arabicspeaking populations, the Southeastern Anatolia region has long frustrated statist ideals of a modern, developed, and unified Turkey. The transformation of water - society relations through massive damming and water transfers, therefore, should be understood as a means not only to realize the hydro-economic development potential of southeast Turkey, but also to transform the social geography of the region - often characterized as 'backward', overly religious, and underdeveloped with respect to both water potential and social ideals.

With the suite of changes associated with the state-led GAP project, the physical and social geography of southeastern Turkey is undergoing rapid and extensive transition; many villages have been inundated to accommodate large dams, while other nearby villages adjust to newly irrigated agricultural landscapes, most evident by the predominance of cotton production. The Harran plain, southeast of the city of Şanl|urfa and extending approximately $60 \mathrm{~km}$ to the border with Syria (figure 2, over), is one of the first areas to experience state delivery of irrigation, representing approximately $10 \%$ 
of the total of nearly 1.7 million ha that are eventually expected to receive agricultural water from the Tigris and Euphrates rivers. Members of Turkey's Arabicspeaking and Kurdish-speaking minority communities inhabit the Harran plain: with estimates of approximately $80 \%$ of villagers in the plain speaking Arabic as a natal language, and the remaining $20 \%$ of villagers being primarily Kurdish speaking. ${ }^{(3)}$

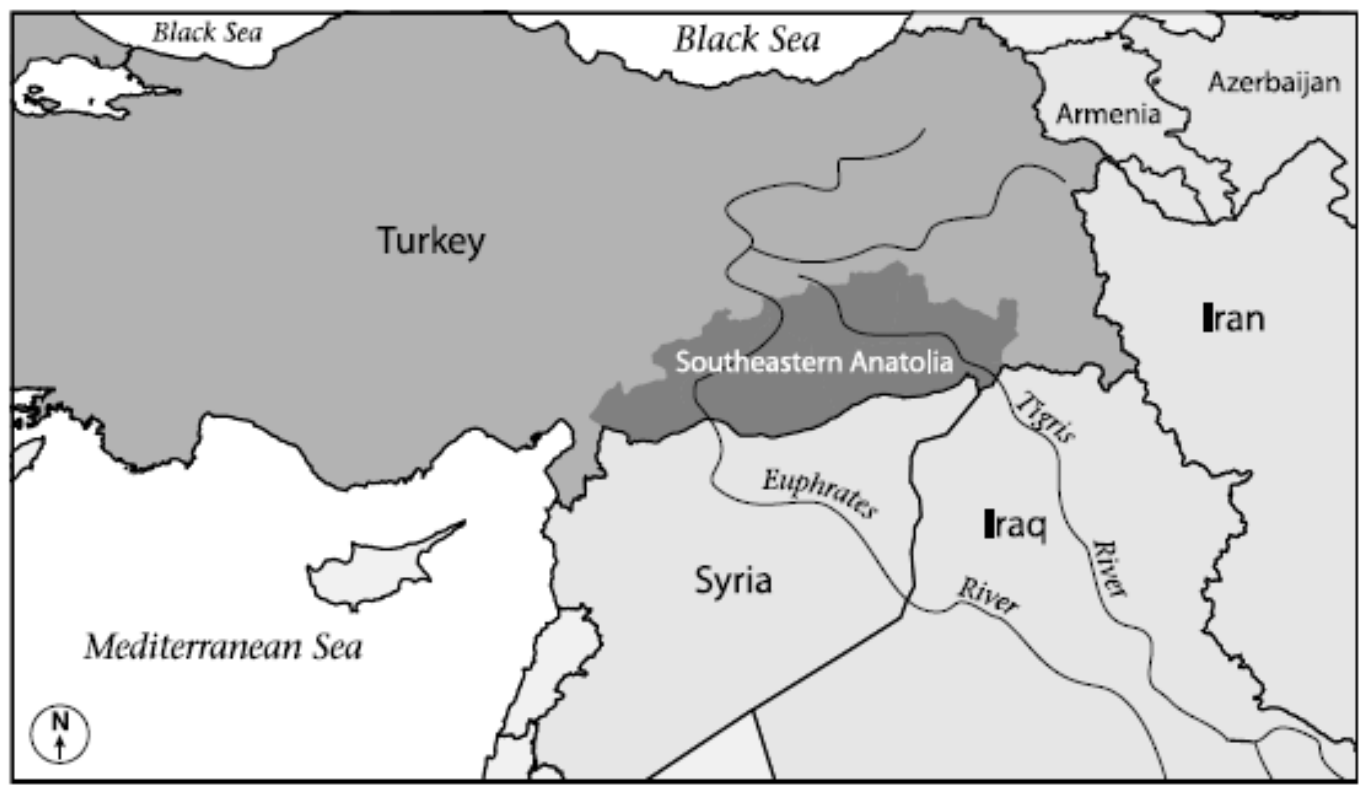

Figure 1. The Southeastern Anatolia Administrative Region, highlighted here in the darker gray, is the target region for the Turkish state development effort known as GAP. As highlighted on the map the Tigris and Euphrates rivers pass through the region. It is also notable that the region borders neighboring Syria and Iraq. (Source: University of Minnesota Cartography Lab, Minneapolis, MN.) 


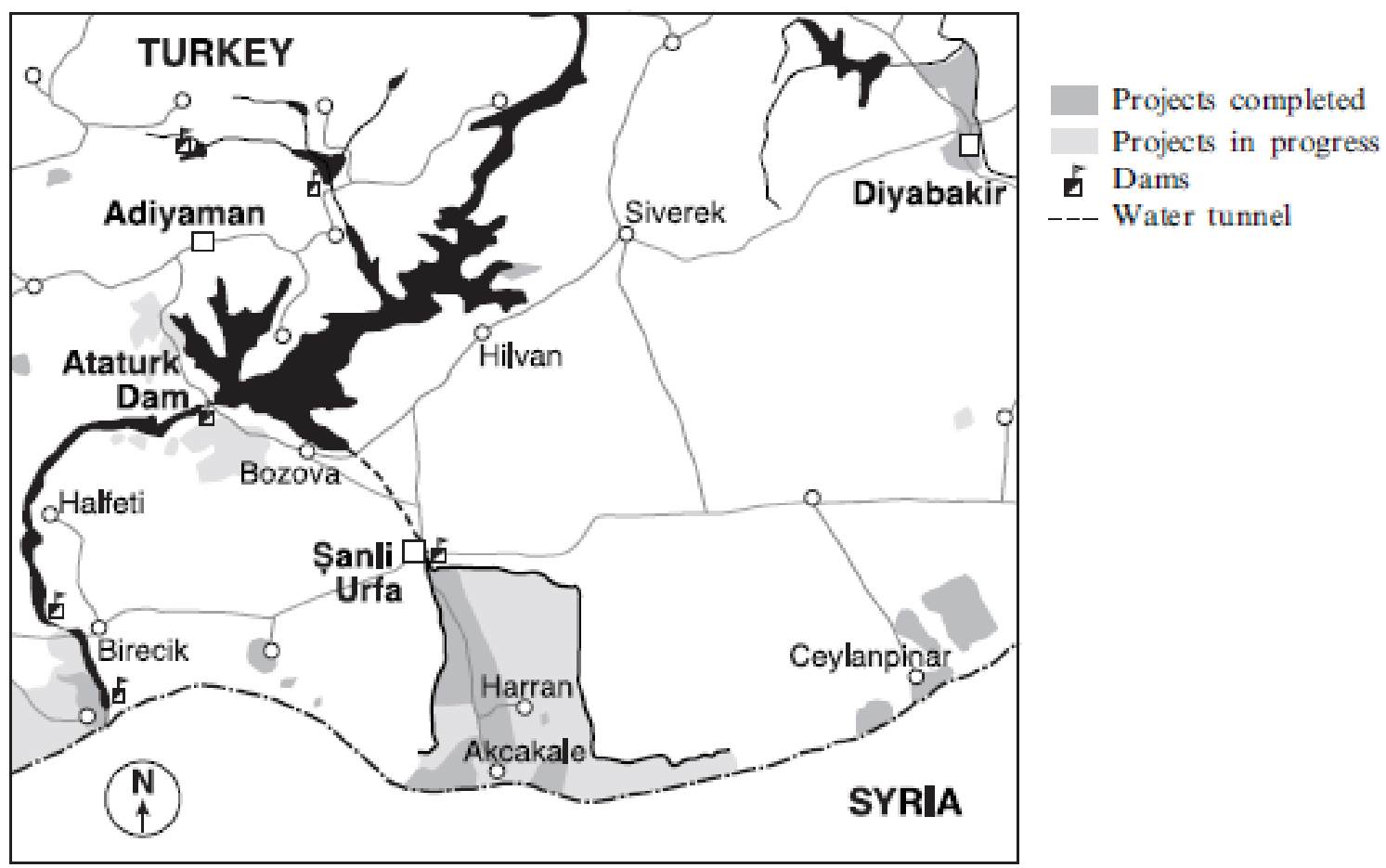

Figure 2. Irrigation projects in southeastern Turkey: the Harran plain (source: modified from original map, Southeastern Anatonia Project, Harita Genel Komutanligi, 1996, 1:2250 000).

Prior to the state delivery of irrigation water from the Atatürk reservoir to the Harran plain beginning in 1995, only a limited number of farmers had access to irrigation by pumping groundwater. The predominant crops before widespread canalet ${ }^{(4)}$ irrigation were wheat, barley, and lentils - crops well suited to the arid conditions and intense heat of the plain. Based on extensive fieldwork carried out in 2001, it is clear that, after nearly a decade of canalet irrigation, residents of the plain have witnessed a wholesale transition of livelihoods, crops, and material conditions. In the following sections I trace these changes, focusing on changing water uses and water management as daily practices that are important to the rearticulation and maintenance of a suite of social inequalities and notions of difference, including gender.

\subsection{Changing uses of water: landlessness, livelihoods, and ethnicity}

Less than a decade after the arrival of irrigation, over $80 \%$ of the Harran plain is now dedicated to cotton production. This number is shocking in light of the fact that cotton constituted approximately $2.5 \%$ of the earlier cropping pattern for the Southeastern Anatolia region on the whole, and planners estimated that cotton would eventually constitute approximately $25 \%$ of the irrigated crop pattern (GAP Regional Development Administration, Ankara, 1998, http://www.gap.gov.tr). ${ }^{(5)}$ This new use of water intensive irrigation to support cotton as a predominant $\operatorname{crop}^{(6)}$ is one of the most 
significant changes for the social and physical geography of the region. Landlessness, livelihoods, and emerging intraregional disparities are all key parameters of social difference that are being actively renegotiated in relation to these new crops and irrigation uses.

Landlessness is a particularly acute problem in southeast Turkey. In the Harran plain current estimates of landlessness are approximately 35 - 40\% of the population - for example Ünver (1997) cites 1991 figures as 37\% - with many landless farmers working as sharecroppers on a $30 \%$ share basis. Few women have formal title to lands, and, among those who do, most often they were designated in name only to avoid the transfer of land titles during failed land-reform efforts of the 1970s or thereafter (for example, a landowner may have transferred title to sisters or daughters to avoid having to revert lands above a designated allowable amount). ${ }^{(7)}$ Thus, commonly cited landlessness figures fail to account for the fact that the disaggregation of men and women would reveal rates of landlessness closer to $80 \%$ of the adult population. ${ }^{(8)}$ This is important to note for the later discussion of the participation of women in water user groups, ${ }^{(9)}$ given that formal participation is generally limited to those with formal land title.

Based on extensive interviews with men and women in the plain, landowners appear to have reaped significant benefits with irrigation. Many landowners note income increases that have enabled the purchase of new cars, cell phones, or tractors. By contrast, those without lands often note that they have been left behind. As Adile, a landless Kurdish woman in her forties, laments "We were left more backward." She continued to explain that, since irrigation, those with land and money only want to buy gold, cars, and quarrel over title to lands, adding 'the difference between those who have lots of land today and tomorrow will be clear when we all go to the same little grave when we die. We'll all be in the same sized place' (interview 10 October 2001). ${ }^{(10)}$ Adile's comment reflects a commonly expressed perception that, with the coming of irrigation, rich farmers have benefited disproportionately, leaving a larger relative gulf with poorer and landless farmers. Similar sentiments were expressed by many others, including a 29-year-old Kurdish male who said: "It destroyed the people who were busy with animal husbandry. But it profited those who had land a lot, and it made those who have land to be able to have some savings" (Harris and Karahan Kara, 2001, survey A11). With the rising land prices associated with irrigation, and the continued inability of landless farmers to access credit, purchasing lands appears increasingly out of reach for many.

The growing divide between landed and landless farmers is further reinforced by the fact that, with cotton production, certain supplemental means of income generation are less available. In recent years, animal husbandry, a livelihood that has long provided an important source of income for villagers, has experienced a drastic decline with herd sizes currently being a fraction of what they were in previous decades. ${ }^{(11)}$ Prior to irrigation, animals could be herded on wheat and barley fields after harvest. Now, with altered cropping seasonalities and the intensities associated with irrigation, grazing land is less available. Women in families engaging in animal husbandry would often sell cheese, yogurt, or wool from animals to earn extra income for their families. Further, many of the subsistence needs of families could be met by growing wheat, barley, or lentils, and by using meat, yogurt, and wool from animal herds - through direct, and 
relatively equal, contributions of male and female members of households (with women often charged with preparing milk, yogurt, barley, or wheat for bread making, and also with drying wool to make bedding, among other tasks). With irrigated fields now dedicated to cotton, landowners no longer allow grazing on their fields, and sharecropping farmers have no choice about which crop will be grown. Consequently, farmers no longer grow as many crops that they can consume directly, with wheat, wool, and yogurt now increasingly bought in the market rather than produced at home. A notable exception to this is small plots of vegetables - especially pepper, eggplant, and tomatoes, now grown for home use - which are also generally considered to be women's labor. ${ }^{(12)}$

Perhaps the most striking results of our 2001 survey of the social changes accompanying irrigation relate to animal-husbandry issues. Over $75 \%$ of respondents noted that in general irrigation has been either 'very positive' or 'positive' for their village. By contrast, when asked directly how they have experienced the loss of animals in the plain, $85 \%$ of respondents said the loss has been 'negative' or 'very negative'. The primary reasons for the decline of animal herds cited by villagers include irrigation and the associated loss of grazing lands. Several farmers noted that they would prefer to grow wheat or other crops but are subject to the decisions of landowners. One 29year-old Kurdish male noted: "It was said that GAP is happiness, GAP is survival. But, it was a like a suicide pill for those of us who are animal breeders, it prepared our end. Right now [even thinking of it] GAP gives me discomfort" (Harris and Karahan Kara, 2001, survey A11). The loss of animal husbandry as a viable livelihood has proven to be especially critical for landless families, as many of them now have only their labor to fall back on, without the ability to use animals to provide for basic needs or to sell them in times of difficulty. An elder farmer bemoaned: "In the past, we would not hesitate to slaughter a sheep when guests came, but now ... we don't have such an opportunity" (Harris and Karahan Kara, 2001, survey A31). In sum, the decline of animal husbandry has meant the loss of prestige for many (for example, the inability to provide animal meat to guests or to celebrate feasts), and also the loss of insurance against crop failure or other difficult times (being able to sell off animals when needed). As such, this 'new enclosure movement' (Katz, 1998) associated with irrigation has severely curtailed access to land resources and certain livelihood possibilities on the plain. As suggested, the way that irrigation affects residents differently depending on their predominant livelihood strategy also has a significant gender component, given that the relatively equal male and female contributions to household needs with subsistence production have now largely been supplanted by market-dependent irrigation crops, effectively enhancing men's relative contributions to the household economy (discussed below).

The changing livelihoods associated with irrigation have also meant other important social changes. One benefit of irrigation delivery to the Harran plain is that residents no longer have to travel to Adana or other areas to find work during the cotton-harvest season. This is a change celebrated by the GAP administration and noted positively by residents: "We now have a more positive attitude towards the state because before we had to travel to places like Adana but right now we are working in our own fields directly in front of our houses" (Harris and Karahan Kara, 2001, survey A3). In fact, workers from elsewhere are now coming to the plain as seasonal laborers. Large work groups - 
often comprising young children and teenage girls, and commonly supervised by several elder men - are working to harvest cotton on a per-kilo basis for periods of two to three months in the fall.

Somewhat ironically, those who have not yet realized the benefits of irrigation directly and are still forced to travel as seasonal migrants are primarily migrating from villages in Adiyaman and other areas to the north, including from villages near to the Atatürk dam reservoir, the source of irrigation waters. The fact that these nonirrigated areas are predominantly Kurdish, and that the first irrigated areas are majority Arabic speaking, highlights ethnic difference in relation to the new waterscape. This coincidence of geography is noted by some of the Kurdish residents as evidence in their minds of inequities propagated by state agents in terms of preference for the delivery of water. As a group of Kurdish seasonal migrant workers sitting around a fire after a day of work noted:

"They gave Arabs the water first, but not to us, we are Kurdish. This is not life. We will work to pick 100 decars of cotton. In Bozova, we also own 100 decars, but since there is no irrigation, our pistachio and nut trees don't give fruit soon after we plant them so we came here to get some money. We don't think we will earn good money here either, but we are obligated to come pick cotton." (field notes based on research carried out in in the province of Şanl|urfa, May November 2001).

This and similar statements indicate that some Kurds feel left out of the benefits associated with irrigated agriculture. As such, the spatially (and ethnically) differentiated access to irrigation resources seems to be creating new tensions and intraregional disparities. More centrally, these sentiments also reveal the ways that the changing water-resource geography in part serves to redefine meanings and associations attached to what it means to be 'Kurdish' or 'Arab' in this context. Kurdish speakers are increasingly associated with seasonal workers (the numbers of Kurds in the plain swell during the harvest season), ${ }^{(13)}$ and 'Arab' is increasingly associated with farmers who employ them and have privileged, or at a minimum more immediate, access to water. Consequently, although one of the principal aims of GAP development is to increase development in the Southeastern Anatolia region to overcome long-standing disparities with the rest of the country, the emergent waterscape also appears to be creating new intraregional disparities, enabling a differentiated social geography whereby some Kurdish residents feel as though their interests have, once again, been overlooked. Even within the plain there are stories of favoritism related to the timing of when villages receive irrigation, which are sometimes told along ethnic lines. These are several of the ways that terms of difference are taking on new meaning and importance in relation to the new water-resource geography of the region. How residents understand themselves, and each other - as Kurdish or Arab, or as landed or landless - is now necessarily read through experiences of water-resource access, use, and change, which are so important to new economies, livelihoods, and institutions in the region. Yet another example relates to state-sponsored water user groups, which similarly create new patterns of inequality in relation to access, prestige, and power associated with the management of water as a critical resource. 


\subsection{Management of water: water user groups and knowledge}

Paralleling the effects of irrigation uses, new water-management institutions and practices have also served to solidify, cement, and rigidify social-power differentials in certain ways. Different axes of power (gender, landholdings, or aşiret) ${ }^{(14)}$ that have existed in the region for many years, in many forms, have found new expression in the emergent water geographies of the region.

In an effort to promote democratic management of water resources, and maximize irrigation benefits for residents, the Turkish state has helped to form a series of water user groups throughout newly irrigated areas. In principal, these groups allow farmers to make collective decisions about water distribution, maintenance, and management, and they provide a decentralized structure for the collection of water fees, election of irrigation officials, and farmer training. The groups are also meant to provide linkages between water users and the state water agency (by relaying information about irrigation needs and the timing of water transfers). However well intentioned, water user groups have at times proven to be a vehicle of corruption and injustice, often providing those already in positions of power with access to resources (to the extreme with the frequent embezzlement of funds), discretion over hiring and firing of employees (at times resulting in nepotism), and power and prestige for those voted into office (often along aşiret lines and typically electing large landowners and village heads).

The 'democratic' structure of the user groups is also cause for concern. For instance, although in principle all farmers are meant to democratically elect representatives to the council, many report that they are not given such opportunities. Landless residents are also effectively barred from participation given minimum landholding requirements written into the legislation in terms of who may vote, or serve as a representative to the user groups. The minimum landholding requirement, coupled with social barriers, also pose significant barriers to women's participation in irrigation management. As noted, few women hold formal title to land, meaning that the structures of the user groups enforce, rather than overcome, sociocultural barriers. I provide more details on the operation and outcomes of the user groups, including gender dimensions elsewhere (Harris, 2005). For purposes of this discussion, suffice it to say that there are a number of ways that the user groups have effectively served as mechanisms of state-sanctioned insistence on 'difference', excluding some (notably women and landless residents) from the irrigation management possibilities and associated benefits. As such, the irrigation associations are yet another aspect of the emerging waterscape that appears to retrench and exacerbate certain power divides and operations of social difference. In this context, not owning land comes to mean not only being without control and access to land, but also being without a role in water resource management.

A further example of how difference is (re)produced in relation to the new irrigated landscape relates to ways that diverse irrigation knowledges, training experiences, and skills are invoked and practiced, particularly through training and extension activities of water user groups. Farmers and state agents in the Harran plain often draw on discourses about scientific irrigation management that serve to distinguish certain 
farmers and practices from others, making claims about scientific irrigation and appropriate water uses in a way that situates certain farmers as backward vis-a' -vis technological farming practices, state authorities, and the 'West' (compare Gupta, 1998). For example, GAP agents frequently invoke the lack of knowledge and training among farmers, blaming farmers' irrigation practices for the desertification and salinization problems emerging in the plain. When a powerful landowner complained of the monocropping of cotton and the resulting soil quality and pest problems in the plain, he echoed common discourses that circulate among state agents by noting widespread illiteracy as the reason for this (interview 21 September 2001).

These discourses invoke difference in terms of having or lacking knowledge of appropriate irrigation practices and techniques, retrenching divides between those who are literate and those who are not, or between those who participate in wateruser-group training, and those who do not. ${ }^{(15)}$ Given that many farmers, particularly women, are formally illiterate, and with noteworthy portions of them not speaking Turkish at all, these divides often fall along gendered and ethnic lines. In some respects, ideas of (in)appropriate farming are thus redefining the very category of 'farmer' in relation to irrigated crops, at once devaluing agricultural knowledges associated with wheat production or animal husbandry. Some farmers, obviously responding to such claims, actively assert their agricultural knowledge in opposition to the knowledge claims of state agents and engineers. As one Arab farmer facing severe salinization noted: "Many agricultural engineers and others come to talk with us about water use, fertilizer, etc but every farmer is as knowledgeable as an engineer right now. The engineers just study with the books in his hand, but we, the farmers, live with the soil. So, we know better than the engineer what the soil needs" (interview 16 October 2001). 'Difference' in the plain, therefore, not only depends on issues of ownership or access to land and water, but is actively negotiated and contested in relation to perceived ability to manage and maintain those resources.

To reiterate, water user groups provide access to resources and prestige for some, while excluding meaningful participation of landless families, women, and less powerful farmers. Water-management institutions and discourses have thus somewhat amplified demarcations of difference among populations, citing 'difference' according to landholdings, appropriate knowledge, or gender. Consequently, water user groups, coupled with other socioecological processes associated with irrigation, have tended to cement networks of power, rigidify and redefine notions of difference, and effectively widen the gulf between those with access to power and resources and those without. ${ }^{(16)}$

\section{HOW GENDER MATTERS FOR IRRIGATION}

The discussion of how certain individuals are marginalized from emerging water uses and management practices is only part of the equation of how gender is important for understanding changing nature - society relations in newly irrigated areas. In general, 
for many women of the plain, irrigation has meant an increased work burden, greater difficulty in meeting family subsistence needs, and, as discussed below, the simultaneous and contradictory devaluation and valuation of their work. Men, by and large, have enjoyed enhanced prestige associated with irrigation and other technological modes of work, through the purchase of status items (including the ability to obtain second or third wives), new mobility for those now able to purchase automobiles, as well as renewed household decisionmaking influence associated with the transition from subsistence to market-based agricultural production.

Although these overarching trends are evidenced, nature - society relations associated with the irrigated waterscape clearly have contradictory and differentiated implications for different men and women. Some men unquestionably experience increased stress and loss of prestige associated with the inability to meet family needs in difficult times. Also, wives and daughters of rich landowners may now enjoy a reduced work burden, the prestige associated with not having to work in the fields, the ability to send children to school in the city, or the opportunity to travel to participate in the hajj, which might have been prohibitively expensive before irrigation. One of the most notable differences between women also relates to age and generational differences - for instance, mothersin-law exert considerable control over the labor of daughters-in-law. ${ }^{(17)}$ I focus here, however, on overarching trends, illustrating these with discussions of the changing labor economies associated with irrigation and the associated changes in the market for brides as well as the increased reliance on market transactions.

\subsection{The new labor economy: bride price}

The new dominance of cotton in the Harran plain has meant an altered labor economy with a heightened need for many hands, particularly to engage in the labor-intensive tasks of weeding and picking, largely performed by women, teenage girls, and small children. Although, occasionally older men may be seen with large groups working in the fields, they are often performing a mix of supervisory and hands-on work. Table 1 details survey responses related to the gender division of agricultural labor. Based on these responses, the care of children, cooking, and cleaning are largely associated with feminine labor, whereas marketing crops, driving tractors, irrigation, applying pesticides, and important decisionmaking are examples of tasks considered to be masculine work. With respect to the cotton harvest, it is notable that a strong majority of survey respondents noted this as both masculine and feminine labor. 
Table 1. Gender division of labor according to survey data, taken from Harris and Karahan Kara (2001) survey in Harran plain.

\begin{tabular}{|c|c|c|c|c|c|c|}
\hline Work task & $\begin{array}{l}\text { Adult } \\
\text { men }\end{array}$ & $\begin{array}{l}\text { Adult } \\
\text { women }\end{array}$ & $\begin{array}{l}\text { Both } \\
\text { men and } \\
\text { women }\end{array}$ & $\begin{array}{l}\text { Male } \\
\text { children }\end{array}$ & $\begin{array}{l}\text { Female } \\
\text { children }\end{array}$ & $\begin{array}{l}\text { Male and } \\
\text { female } \\
\text { children }\end{array}$ \\
\hline Care of children & 0 & $\begin{array}{l}101 \\
(86.3)\end{array}$ & $\begin{array}{c}16 \\
(13.6)\end{array}$ & 1 & 32 & 5 \\
\hline Cooking & 0 & $\begin{array}{l}113 \\
(96.5)\end{array}$ & $\begin{array}{c}4 \\
(3.4)\end{array}$ & 1 & 25 & 1 \\
\hline Cleaning & 0 & $\begin{array}{l}115 \\
(98.2)\end{array}$ & $\begin{array}{c}2 \\
(1.7)\end{array}$ & 1 & 32 & 2 \\
\hline Irrigation & $\begin{array}{l}108 \\
(92.3)\end{array}$ & $\begin{array}{c}5 \\
(4.2)\end{array}$ & $\begin{array}{c}4 \\
(3.4)\end{array}$ & 30 & 1 & 3 \\
\hline Hoeing & $\begin{array}{c}74 \\
(64.3)\end{array}$ & $\begin{array}{c}6 \\
(5.2)\end{array}$ & $\begin{array}{c}35 \\
(30.4)\end{array}$ & 10 & 2 & 28 \\
\hline Harvesting lentil, wheat & $\begin{array}{c}6 \\
(5.4)\end{array}$ & $\begin{array}{c}53 \\
(48.1)\end{array}$ & $\begin{array}{c}51 \\
(46.3)\end{array}$ & 7 & 2 & 21 \\
\hline Harvesting cotton & $\begin{array}{c}4 \\
(3.4)\end{array}$ & $\begin{array}{c}6 \\
(5.2)\end{array}$ & $\begin{array}{l}105 \\
(91.3)\end{array}$ & 0 & 0 & 56 \\
\hline Marketing crops & $\begin{array}{l}107 \\
(93)\end{array}$ & $\begin{array}{c}4 \\
(3.4)\end{array}$ & $\begin{array}{c}4 \\
(3.4)\end{array}$ & 8 & 0 & 1 \\
\hline Driving tractors & $\begin{array}{l}108 \\
(94)\end{array}$ & $\begin{array}{c}2 \\
(1.7)\end{array}$ & $\begin{array}{c}5 \\
(4.3)\end{array}$ & 24 & 0 & 4 \\
\hline Weeding & $\begin{array}{c}24 \\
(21)\end{array}$ & $\begin{array}{r}16 \\
(14)\end{array}$ & $\begin{array}{c}74 \\
(64.9)\end{array}$ & 2 & 3 & 29 \\
\hline $\begin{array}{l}\text { Applying pesticides } \\
\text { and herbicides }\end{array}$ & $\begin{array}{l}111 \\
(97.4)\end{array}$ & $\begin{array}{c}1 \\
(0.8)\end{array}$ & $\begin{array}{c}2 \\
(1.7)\end{array}$ & 15 & 0 & 2 \\
\hline $\begin{array}{l}\text { Making important } \\
\text { decisions }\end{array}$ & $\begin{array}{l}92 \\
(78.6)\end{array}$ & $\begin{array}{c}1 \\
(0.8)\end{array}$ & $\begin{array}{l}24 \\
(20.5)\end{array}$ & 6 & 0 & 2 \\
\hline Caring for animals & $\begin{array}{l}23 \\
(20.7)\end{array}$ & $\begin{array}{l}36 \\
(32.4)\end{array}$ & $\begin{array}{c}52 \\
(46.8)\end{array}$ & 4 & 3 & 30 \\
\hline Driving cars & $\begin{array}{l}103 \\
(88.7)\end{array}$ & $\begin{array}{c}2 \\
(1.7)\end{array}$ & $\begin{array}{c}11 \\
(9.4)\end{array}$ & $* *$ & $* *$ & $* *$ \\
\hline \multicolumn{7}{|c|}{$\begin{array}{l}\text { Notes. Number of respondents who indicated each response is denoted, with percentage of } \\
\text { respondents noted in parentheses. Responses that received a strong majority of responses are } \\
\text { noted in bold. Some respondents also noted certain activities as appropriate for children, } \\
\text { revealing some patterns in terms of divisions of labor (although this response was not requested } \\
\text { explicitly). }\end{array}$} \\
\hline
\end{tabular}

Although this could be taken as evidence against my claim that the cotton harvest is carried out primarily by young women and male and female children, my observations during the cotton-harvest season were that these were largely feminized and children's tasks. Men from the early teens and older were rarely observed in the fields, and, when they were, they were often there to oversee a family of laborers working on their behalf. Among families that carried out the cotton harvest without hiring wage laborers, this responsibility again fell primarily to children and young unmarried women. In such cases, adult men would participate sporadically, often staying at home while their wives or siblings were out in the fields.

Regardless of the gender division of adult laborers for the cotton harvest, the transition to irrigation and to the associated cotton cropping has meant that, for some, it is beneficial to have more children, or more wives (polygamy is practiced), translating into 
more hands for picking cotton, and in some cases eliminating the need to hire seasonal laborers. Arguably, cotton would not be an economically feasible crop, given labor requirements, if it were not for access to childrens' and gendered labor within households and between communities. In some senses, young women and children provide a shadow subsidy for cotton in a way that can be argued to subsidize both landowners and the Turkish state as the principal buyer of cotton (cotton is a regulated market, with prices fixed by the state). ${ }^{(18)}$

Particularly noteworthy for the discussion of irrigation and gender dynamics is that the need for increased labor provides incentives for increased natality or to keep children out of school. Additionally, this new labor regime and economy associated with cotton production have altered the politics, and price, of marriage in several critical ways. The tradition of bride price (başl|k parası), ${ }^{(19)}$ generally paid to the father of a girl for marriage, is especially common among Arab families. Alternatives to bride price include süt parası (milk money), a much smaller sum said to compensate a girl's mother for her milk, which is more common among Kurdish families, or an 'exchange' arrangement (değişik or berdel), whereby a daughter is exchanged for a girl from another family. The tradition of bride price is in many ways an explicit marriage market, with many men using the language of 'buying' or 'obtaining' wives (they use the verb almak, 'to take' or 'to purchase'), ${ }^{(20)}$ and with many young men complaining that the high price of brides makes marriage unattainable. As with any other market, there is also the underlying assumption that goods are substitutable: for example, one bride is equal to one car or to one daughter (this notion of substitutability is present in both the başlık paras| and the değişik arrangements).

As noted by Ayça, an 18-year-old Arabic-speaking girl of a rich muhtar (village head), a girl will often hear she will be married, perhaps to a boy she has never met, and she may be living with the groom's family within a week. She and her sisters also noted that often the decision is made to take a bride dependent on the availability of money or similar issues, and a girl will be actively sought out, with family members traveling around to neighboring villages to select a girl of appropriate age and status that they might be able to afford (price is largely dependent on the girls' family status and landholdings, but beauty and other factors may also come into play). Ayça compared herself and her unmarried sisters to the family's sheep, noting that they are kept around until money is needed, then they are sold. She also suggested, with a wave of her hand across her neck, that if they stray from social expectations, like a sheep from its flock, they would be killed (referring to stories that circulate about girls who are killed for betraying a family's honor by attempting to marry according to their own wishes). Many young girls dread their inevitable marriage, with some noting that fathers seem to care only about the money. The phrase, 'bekarl|k sultanl|k' (being single is like being a sultan) is repeated by many young girls in expectation of the intense work that they will undertake as married women, as well as the loneliness they anticipate in moving to a husband's unfamiliar village. ${ }^{(21)}$ The practice of bride price is not new, but is taking on a new importance in relation to the irrigated labor economy.

In the recent years, coincident with irrigation, bride price has increased considerably. Among survey respondents, $82 \%$ of respondents agreed that bride price has increased dramatically over the past five years. While I conducted fieldwork in 2001, bride price 
was frequently cited as minimally 8 billion TL, and up to as much as 15 billion TL. This is significant - it is the equivalent of approximately $\$ 5000$ - $\$ 10000$ at the time, and up to two times the average per capita income in the plain of approximately $\$ 4000$. The labor imperative of cotton makes the addition of a young bride or the loss of an unmarried daughter very important for family labor balances. Much of the work that young brides engage in, as well as discourses around a bride's obligations to her new family, suggests that, in some senses, she is a hired laborer, especially to provide for the needs of her husband's parents as they age (in addition to perhaps the most critical of her duties, to bear children, which meets obligations to carry on the lineage and earns prestige for herself and her husband, particularly through the birth of sons). ${ }^{(22)}$ Interestingly, it is common for the entire family, rather than just the husband, to refer to a new bride as 'our bride' or gelinimiz, with the term for bride, gelin, translated literally as 'the one who came'.

While conducting interviews I heard of several instances of young brides having run away to their families of origin, complaining of the heavy work burden at the homes of their in-laws. There was also visible evidence of daughters-in-law doing much of the work. In one house I asked why a bride carried a large sack unassisted by the unmarried girls of the family. The sisters replied that this is natural as she is the sisterinlaw and has young children and therefore has more mouths to feed. We also met with a mother-in-law on a morning when her daughter-in-law had escaped for the fourth or fifth time, as she was upset about having to work in the fields of her in-laws, especially as her husband was away for nearly two years in the military. The bride left saying 'I don't have a son or a daughter, my husband is not here, so then why do I have to work for you under the sun all day in the cotton fields?' The mother-in-law recounted that she was so upset that her 'bride' had escaped that she cried all morning; but she was reassured knowing that the girl would have to return if they sent for her to maintain her family's honor. When we asked whether the girl's parents accept her into their house when she runs away, the mother-in-law responded: 'Sure. It's indeed her parents who encourage her to come back all the time, telling her that she should not work in our fields but should come back and work in their fields. During work [cotton harvest] time, one laborer is one laborer, it is worth a lot. And during other times, her parents go elsewhere to pick other crops, so they always need an extra worker' (interview, 25 September 2001).

As these stories illustrate, irrigation has in some respects heightened the value of women's labor, which is explicitly articulated in the form of increasing bride price. (23) There is also a somewhat contradictory devaluation of women's work evidenced by statements made by farmers. It is generally considered prestigious for a man to be able to provide for his wife so that she does not have to work in the fields. ${ }^{(24)}$ Perhaps consequently, many men we spoke with insisted, with pride, that their wives do not work at all. As one older farmer in a southern village near the border with Syria stated: 'Women in this village do not do any work. They don't go the fields. They just make bread' (interview, 24 September 2001). At the time he spoke there was a group of us sitting, talking, and drinking tea, and watching a young bride and her mother-in-law make bread over an outdoor fire, which was perhaps the reason why he was willing to concede bread making as one form of work women do engage in. The young bride, in 
response to his comment, looked up and stated: 'We also work hard. Is this not work? I'll also go [to the fields] to pick cotton tomorrow' (interview, 24 September 2001). This narrative was invoked repeatedly, most often with husbands making claims that their wives do not work but 'just sit'. Women in rich families noted, too, with pride, that they do not work at all but only sit, or perhaps watch television. Such erasures of women's contributions to the household, or of domestic labor generally, have the effect of enhancing men's status as providers for the home and as principal decisionmakers within the household.

The statement made by the farmer limiting the women's contributions to the task of baking bread is also perhaps indicative of another trend. With irrigation, and the predominance of cotton, many women no longer engage in the types of direct subsistence they might have previously. For many families, they note that, in the past, women used to process their own bulgur and flour, make yogurt, or make beds from sheep's wool. Now many of these items are purchased in the city, including flour to produce traditional village bread. So, for some, it may appear that women are in fact working much less to meet family needs. Bread making, small-scale yogurt production, and drying of spicy peppers are among the few women's household subsistence tasks that have not been wholly supplanted by market transactions in the new irrigated economy. With these sorts of changes, women's direct contributions to the household are being replaced with less-prestigious, indirect contributions to the household economy through participation in cash-crop production, such as cotton harvesting.

\subsection{Increased market reliance}

The increased reliance of rural residents on market goods has augmented the need for cash income, also requiring money-management skills. In contrast to subsistence agriculture where men and women may be considered to contribute relatively equally to meeting household needs, with the predominance of cotton farming, cotton must be exchanged for money, and new goods must be purchased through the market. Because men typically control decisionmaking with respect to market purchases, ${ }^{(25)}$ and because women are often not allowed to travel to urban areas, increasing market reliance has effectively meant consolidation of men's control over important family decisions, and increased reliance on men's roles and contributions to the household.

The eventual delivery of irrigation water to nearly 1.7 million ha throughout the GAP region is intended to benefit local residents by increasing work opportunities, crop diversity, and agricultural productivity. In fact, planners are celebrating estimates that per capita average incomes in pilot areas of the Harran plain more than tripled in the first year of irrigation delivery alone, from an estimated \$1034 in 1994 to \$3963 in 1995 (Ünver, 1997, page 466). Noting income increases, however, masks that during this same time period expenses for many families were also rising. In response to survey questions along these lines, $77 \%$ of respondents said their income had increased since irrigation delivery, and $79 \%$ noted that their expenses had increased. As evidenced by innumerable other studies of the transition to cash economies, more money in the hands of decisionmakers also does not necessarily translate into an improvement in the 
quality of life or well-being of different family members (for example, Agarwal, 1986; 1988; Kabeer, 1994; Kandiyoti, 1990). In fact, some wives complain that their husbands prioritize expenditures on gasoline, automobiles, or cafes over expenditures on health, food, or education. In some cases these problems have been particularly acute given perceived windfalls of income at the end of the cotton season. Perhaps never having learned cash-management skills with subsistence production, some decisionmakers overspend or gamble away cash rather than saving or investing it to keep the family going throughout the year. ${ }^{(26)}$

Responding to the question of "what has changed in your village since irrigation?" rural residents frequently cite changing material conditions, noting the escalating number of cars, cell phones, and cement houses, as well as the ability of richer men to purchase second and third wives - all visible status items that are considered to reflect the success of male household heads. As one man living in a predominantly Arabicspeaking village remarked: 'If a man already has a car and a tractor, then he gets some additional money, he will get a second wife'. Another farmer in his fifties justified his decision to seek a second wife: 'What would a car be without a spare tire? If something should happen, you need a spare'. When respondents were asked what villagers tend to purchase when they have additional income, 'they marry a second or third time' was cited by approximately one third of survey respondents. The general category of 'they marry' (including first wives) was the third-ranked response for the primary use of additional income, just behind tractors or cars and houses or land (which were first and second, respectively).

The increasing incidence of cars throughout the plain, a visible and often-cited change, is itself particularly noteworthy in terms of the gender dimensions of ongoing social changes. Cars tend to be driven exclusively by men, expanding men's mobility, scales of interaction, and, consequently, their access to resources, information, and contacts in other villages or in urban areas. One Arab man responded when asked about changes with irrigation: "life has become better, people live in luxury, the city is so close to us now" (Harris and Karahan Kara, 2001, survey A15). With this quote he is directly referring to the ability to travel more easily to the city, making the city 'closer' for men but not necessarily for women, who often remain in the spaces of the village. This new mobility for men, and the access to opportunities and resources it affords through an expanded geography of interaction effectively widens gender differentials between men and women in ways that parallel my arguments about redefinitions of Arabs and Kurds or about widened gaps between landed and landless farmers. Further, men can now frequent urban spaces where they might be relatively anonymous and beyond the sight of others known to them who could monitor their activities, an opportunity rarely, if ever, afforded to women. In the context of these sociospatial changes, it is also worthwhile to note that much work on gender in urban areas of Turkey focuses on women's new mobility and extended social networks through changing spaces of consumption such as the shopping mall (see Durakbaşa and Cindoğlu, 2002). Many such works suggest that changing relationships to consumption and modernity have lessened women's sociospatial exclusion, widening their spheres of interaction and mobility. Just as Özyeğin (2001, page 45) points out that this has not necessarily been the case for women who live in the many burgeoning squatter settlements around Turkey's 
expanding urban areas, it is also clearly not the case for many women in rural areas, especially those who produce the cash crops that are fueling Turkey's integration into global production and consumption networks and economies. This is one of many important rural-to-urban divides in contemporary Turkey. Within the southeast region, in particular, through the combined effects of gender gulfs in terms of access to education, ${ }^{(27)}$ farmer training and irrigation management possibilities afforded by the new water user groups, or those new mobilities associated with the automobile, many key terms and experiences of 'difference' are retrenched and fundamentally recast.

In all of these senses it is clear that the experiences and subjectivities of men and women, and the associations with masculinity and femininity in general, are fundamentally altered in relation to the irrigated landscape of the Harran plain and the changing water-resource geography of the region generally. Masculinity and femininity take on new meaning as men may increasingly frequent coffee shops and urban markets, or as women are increasingly obliged to stay in the spaces of the village to pick cotton.

Differences between urban and rural, or masculine and feminine, are thus critically recast in relation to the new waterscape and to the differential possibilities and constraints it affords.

As I have suggested, although such gender differences are crucial, they are not necessarily more important or more sustained than other social inequalities that structure the outcomes and situations of different villagers in the plain. As noted, landed and landless farmers, animal herders and farmers, and Kurds and Arabs are also situated differentially with respect to irrigation and the associated crop changes. These differences are not wholly new, however - in some cases inequalities are exaggerated and sharpened, as with the gendered mobility gulf in relation to new access to cars, greater control of men over household needs and market decisionmaking, or the increasing cost of land that keeps landowning out of reach for landless farmers. In other examples differences are simply renegotiated or rearticulated in terms that reflect the new economic, social, and environmental geographies of the region: such as what it means to be Kurdish or Arab, or to be a daughter or son given changing marriage practices in the emerging irrigated economy.

\section{HOW IRRIGATION MATTERS FOR GENDER}

To this point the discussion of gender and of changing water uses and practices is consistent with other familiar approaches, particularly those associated with feminist political ecology or similar traditions. In this section I aim to extend understandings of gender - environment linkages (or connections between social difference and environment generally) by exploring three questions. First, how might gender or other key social differences matter for environmental change, not only in terms of the differentiated effects of environmental change but perhaps also in terms of conditioning environmental transformations from the outset? Second, if we take seriously discussions of intersectionality from feminist theory, how might we more adequately understand connections between social difference and environmental conditions and 
changes more generally, including gender but also taking account of landlessness, livelihoods, ethnicity, or class, and the intersections between them? Third, if we accept that gender is critical to understanding the differentiated effects of, responses to, or knowledges of environmental changes and conditions, how might insights from feminist political ecology engage more fruitfully with gender theory and politics, particularly poststructuralist approaches, to consider 'how categories like 'gender', 'sex', 'race', or 'nature' come to be constructed or stabilized within intellectual, political, and ecological projects" (Moeckli and Braun, 2001, page 124)? To consider these questions I offer some thoughts which draw further on the Turkish example, emphasizing connections between feminist political ecology and other insights from feminist theory and politics.

In terms of the first question, whether gender (or other key notions of social difference) conditions environmental change from the outset, the answer from the Turkish example is clearly 'yes'. Although few works focus expressly on this question, ${ }^{(28)}$ in the GAP case understandings of gender, particularly related to the status and situation of women, are part and parcel of what fuels the alteration of the agrarian and socioeconomic landscape of southeast Turkey from the outset. State planners invoke 'genderregressive' practices that characterize the region (for example, high rates of female illiteracy, high rates of polygamy, and regional natality which is roughly double the national average) as justification for massive state investment in the region. These gender practices are taken as emblematic for the amodernity and underdevelopment of people and places of southeast Turkey (given that the region is home to many Kurdish and Arab residents, again gender practices clearly intersect with ethnicity, religion, and notions of tradition). The developmental ideal in terms of what southeast Turkey should become is also framed in part in gender terms: women's identities, livelihoods, and status are explicitly targeted by GAP development intervention in order to achieve Kemalist ${ }^{(29)}$ or 'Western' ideals. Women's centers, as well as literacy and health efforts, are perhaps the most visible of these programs. As I have attempted to demonstrate, there are also other ongoing development changes associated with the damming and diversion of the Tigris and Euphrates that can and should be read as parallel, implicit, or unintended gender-related transformations. As GAP water-related development proceeds, men and women of the region are forced to literally renegotiate their locations, positions, identities, livelihoods, and knowledges in the face of rapid and extensive waterscape changes. Thus, GAP entails a simultaneous and dualistic, explicit and implicit, approach to gender.

Ethnicity, too, is a key social difference that is clearly central to conditioning the planning and implementation of GAP-related environmental changes. As I have argued elsewhere (Harris, 2002), GAP planning and development are strongly linked to histories of conflict related to the Kurdish issue. As such the project may be in part understood as an economic response to ethnolinguistic nationalist and secessionist movements that have persisted in southeast Turkey over several decades. With respect to both gender and ethnicity, social differences are therefore key in conditioning the nature and extent of waterscape changes. Although relevant to debates in feminist political ecology, the connection between discursive practices and material environmental conditions remains understudied to date.

The second concern I consider as key to extending debates related to gender - 
environment is to interrogate intersectionality with respect to social difference and environment, which would more meaningfully connecting gender to class, ethnicity, livelihoods, and other key factors. Although a number of studies carefully delineate such interconnections - for example, with respect to age and generation in the work of Katz (1991), ethnicity in the work by Carney and Watts (1991), or caste or class in the many works of Agarwal - still more convergence is needed in theorizing these linkages. In the case of rural southeastern Turkey it is clear that gender, landholdings, ethnicity, and livelihoods are all interlinked processes of social difference and inequality that hold relevance for the sociopolitical dimensions of water-related changes. Throughout the analysis presented I have attempted to deal with all of these interconnected threads, emphasizing not only how gender matters for environmental change, but also how livelihood, landholding, ethnicity, or geographic location may be relevant to gender or may even supersede gender difference with respect to exclusions and inequalities. ${ }^{(30)}$

A third issue that I consider as important to extend the body of work on gender environment themes is to engage more directly with other work in feminist theory, particularly poststructuralist approaches. One promising focus in this regard would be not only to theorize how gender matters for environmental change, but also, as I have framed it here, to delineate how it is that environmental change matters for gender. Otherwise stated, how is it that, through environmental conditions or change (in this case irrigation), gender comes to matter at all? The work of Butler is particularly instructive toward this end, particularly her notion of citationality and the related theorization of gender as performatively materialized through practices. Butler posits that gender does not refer to the social attributes of sex difference because the very idea of sex difference already presupposes a notion of gender. She argues that sexed bodies 'matter' because of the "process of materialization that stabilizes over time to produce effect of boundary, fixity, surface we call matter" (1993, page 9). Her use of 'matter' invokes the double meaning of matter as substance (the materiality of physical bodies), and as importance (to be the subject of concern or action). She clarifies her performative theory of gender in Bodies that Matter, noting that the fact that gender is performed does not mean that it is not real, lived, or does not matter: quite the opposite. For Butler, materialization, through iterative practices, is exactly how gender comes to matter, "producing the factness of difference".(31) Although a number of theorists have productively engaged Butler's work and have attempted to overcome its limitations (among geographers, see Nash, 2000; Secor, 2003; Thomas, 2004) for instance, by highlighting labor practices over a focus on language (Weeks, 1998) ${ }^{(32)}$ the primary element I draw on here is to consider gender as a process that makes sense only through iteration, regulation, and repetition, and as practices that hold unstable or shifting meanings, which are sedimented and altered through time and across space.

Following Butler, I take the task for gender theorists, and for feminist geographers in particular, to be not only to explore gender in different contexts, but also to consider the processes and practices through which gender comes to matter at all. To draw on the idea of citationality, which refers to the ways that sex difference is necessarily cited through repetition, it is imperative to consider what processes and practices enable gender to appear as fixed, given, or natural. Particularly when rapid socioenvironmental changes force a transformation of many everyday processes and practices (from crops 
to labor practices), how is it that notions of social difference are maintained or altered with respect to these changes? If sex - gender comes to appear as natural or fixed through iterative practices that cite notions of difference, it is interesting to consider how resilient, malleable, or translatable citational practices are as everyday labor practices, household conditions, contexts, and agro-ecologies themselves significantly shift. In the case-study example, livelihoods, crops, and agricultural practices are all rearticulated in relation to emerging irrigation practices and new water uses. A key task, then, is to trace how it is that idea(I)s of difference, especially sex - gender, are invoked and enrolled in relation to the new waterscape. With respect to themes of interest from feminist political ecology, I argue that changing nature such as the transition to irrigation, potentially serves as a decisive moment in citation, providing valuable opportunities to explore processes of materialization. Whereas Butler would argue that gender is always tenuous and unfixed, I take the scale of changes such as those underway in southeast Turkey to indicate that there are particular moments, such as those associated with profound socioenvironmental change, when gender may be particularly unstable, offering the possibility that these moments present critical opportunities for renegotiations.

In the case of southeastern Turkey, notions of masculinity and femininity, especially appropriate or desirable masculinity and femininity, are central to the work practices performed by men and women. Villagers delineate gendered notions of appropriate labor in response to questions about work responsibilities, expectations for future husbands or wives (for themselves or for their children), and through discussions of the relative merits of educating sons or daughters. Elements often invoked as connoting respectability for men include notions of prestigious work, the ability to father and support large families, and the material conditions of the family (landholdings, cars, the condition of housing, or the ability to keep wives and children from work in the fields). For women, often, appropriate femininity is described through ideals of hard work (leisure is valued if it can be afforded), the ability to mother and care for many children, and obedience to the decisionmaking authority of husbands, brothers, or fathers. Given the changes that have transpired in the past decade, what constitutes prestigious work, what material conditions of families are realizable, and the relative ability to make decisions are all recast in relation to the new conditions of the irrigated landscape. Ideas about masculinity and femininity are thus necessarily redefined and renegotiated, meaning that the very idea(I)s of gender are differentially cited and recast. Perhaps the most dramatic example of how this occurs may be illustrated by the new work category of 'irrigator'.

What comes to be considered appropriate men's and women's work in the context of irrigation is fairly predictable, and interestingly is fairly consistent across a number of other case studies in various contexts - for example, see Ahmed's work in India (1999) or Basnet's work in Pakistan (1992). Irrigation, driving tractors, and other technological facets of agriculture are commonly delimited as male tasks, whereas manual labors (such as harvest of cotton or weeding) are regularly ascribed as female. Many other studies have noted that the mechanization of agriculture tends to increase the agricultural work burden of women, forcing increased work requirements outside the home in addition to the critical reproductive tasks of cleaning, cooking, and caretaking 
that continue to be expected within the home (Agarwal, 1988; Deere and Leon, 1987; Pangare, 1998; Raynolds, 1991).When asked "how has work been affected by irrigation?", $91 \%$ of male and female survey respondents note they are working much more, with a strong majority noting in response to a follow-up question that this is a positive change. Men's labor is required for a host of relatively new tasks associated with irrigation and cotton production, such as the delivery of irrigation water and the application of pesticides. Women, as noted, increasingly engage in manual labor required to maintain and harvest the irrigated crops (see table 1 for survey responses related to the gender division of agricultural labor). Ayça, age 18, says it "used to be better for women in the past, women used to work less, now women only work" (interview, 8 October 2001). In addition to these familiar patterns, how are definitions of masculinity and femininity, or idea(I)s of sex - gender difference, invoked in relation to environmental uses, access, and management?

As irrigation is a relatively recent practice, it is interesting and revealing that there is general agreement among residents of the plain that irrigation remains the domain of men, illustrated by the responses of over $90 \%$ of male and female survey respondents that irrigation is most appropriate as masculine labor. How is it that irrigation so effortlessly and seemingly naturally becomes codified as 'male', rather than there being some other potential association with it as shared or female work? When asked why women do not irrigate both men and women commonly refer to the difficulty of the task (it requires physical force to dig irrigation trenches), as well as the schedule (irrigation operates on a 24-hour schedule). If a woman were to engage in irrigation it would be interpreted as calling into question the physical ability of her husband or male kin. In cases where a woman is widowed men insist that sons or even neighbors undertake irrigation on her behalf. With the actual physical task of irrigation set squarely in the domain of men, the accepted extension is that only men need participate in irrigation training and management (as evidenced with respect to women's nonparticipation in user groups).

Several stories help to illustrate the practices through which the 'difference' between men and women with respect to irrigation is understood, cited, and made to appear as natural. As one Arab farmer explained, women do not irrigate because they cannot do so physically. He continued, with pride, 'At least among us Arabs you will not find any women undertaking irrigation, perhaps among the Kurds you will find a few _ but our women would not do that' (interview, 17 October 2001). Another Arab farmer, Emre, explained that women do not irrigate because it is 'too difficult'. Several minutes later I asked him what he thought was the most difficult job in the village; he responded, 'picking the cotton, but women and children do that' (interview, 19 October 2001).

The idea of a naturalized difference between men and women in terms of their ability to participate in irrigation is brought into question by these two examples. In the first example, it is not only a question of women not physically being able to engage in irrigation labor, as sometimes (as the farmer admits) Kurdish women do irrigate. He assures us that 'Arab' women would not do that. He is clearly invoking notions of appropriate femininity, in this case articulated in relation to understandings of ethnic difference. In fact, in over sixty interviews, I encountered only one woman (indeed Kurdish) who actively irrigates, sometimes with her husband and at other times alone. In 
contrast to what many men emphasize, the difficulty of irrigation labor, she noted that now, since irrigation, "life is easier _ all I have to do is put the siphon in the irrigation canal and the field gets the water itself _ it is easy" (interview, 28 September 2001).

In the second example Emre's idea that irrigation is 'too difficult', and therefore not the domain of women, provides an interesting contrast to the work of picking cotton under the hot sun, which is dominated by women and children and is generally agreed to be the most difficult of agricultural tasks. In our survey, harvesting cotton is singled out as the most difficult task by nearly $40 \%$ of respondents, compared with closer to $5 \%$ of respondents who offered the response 'irrigation' as the most demanding task. It is notable that the vast majority of respondents considered the harvesting of cotton to be suitable for both females and males (see table 1), although, during my observation of the cotton-harvest season, the harvest was clearly dominated by female labor. Although this could be taken as evidence against the idea that the harvest is predominantly feminized labor, it could also be taken to suggest that men and women both participate in masking the work contributions of many women and children (this is similar to statements made that women do not work at all, but rather just sit); or it could be taken to convey that it is possible for many men to engage selectively in feminized tasks, in contrast to more formal strictures that bar many women from engaging in masculinized labor. Interestingly, whereas men can largely enter the female domain of harvesting or caring for children 'at will', women are generally forbidden from engaging in 'men's work'. Such strict barriers hold true for women's inability to drive cars, or to travel without the company of men.

A number of interactions in the field supported the idea that women feel compelled to engage in the cotton harvest. In several cases, women conveyed that their work with the harvest was demanding and beyond their ability to question or oppose. In one instance, a woman returned home from picking cotton feeling sick and dizzy. When we asked why she did not tell her husband she was ill, or ask him to go in her stead, she responded 'It is shameful to ask a man to work. We [women] must do it, otherwise there will not be any food and they will not give us anything to eat' (interview, 14 October 2001). In another nearby village four sisters were responsible for picking cotton while the brothers remained chatting in front of the house with friends. Again, as we spoke with the girls, they noted that their brothers do not engage in the cotton harvest, preferring instead to go to coffee houses or to talk with friends in the village. Many women are well aware that they cannot question brothers or fathers when instructed to go to the fields. In other domains, such as decisionmaking over marriage, the cost of questioning male authority may be as drastic as death in response to a perceived insult to the family's honor and to men's decisionmaking authority.

To consider what is the advantage of maintaining strict divisions of masculine and feminine labor, it is clear that there is a strong economic imperative that is served by citing gender 'difference' with respect to irrigation. Maintaining an unpaid feminine and familial workforce to harvest cotton allows prices to remain low and farmers to make a profit, however meager, after the substantial input costs are considered. As noted, the state is implicated in this relatively underpaid labor market for cotton as a primary purchaser and benefactor of inexpensive cotton to promote the textile industry. It is also remarkable that when asked what the most prestigious job is men commonly respond 
'to irrigate' (and some note 'to work one's own land'), whereas women frequently respond 'to care for children and remain in the house' (although several responded 'to be the wife of an irrigator'). Given the changes that have transpired with irrigation it is interesting to note that the majority of men do now engage in irrigation and only a few rich women do not work in the fields at all. This means that men on the whole appear to be able to realize their notion of prestige and status in their daily work, whereas a majority of women are unable to realize their association between nonagricultural work and prestige. Among women, the only exceptions are either very rich women, or elder women who can comfortably rely on the labor of their daughters-in-law (provided they have borne sons). ${ }^{(33)}$ In this way, women generally experience a relative loss of status and devaluation of their work (moving from subsistence production in the home to agricultural work with irrigation), whereas men's technological labor is considered respectable and more prestigious than their previous livelihoods.

In these interrelated senses changing geographies and environments are key in terms of differentiating labor practices, or spaces of access and influence, which in turn serve to cite and maintain sex - gender and other key social differences. Emergent irrigated waterscapes precipitate new labor, gender, and status geographies. Women increasingly move from work within and around the home to labor-intensive tasks in the spaces of the cotton fields. Men move from the spaces of the village to networks and markets in the cities to purchase pesticides or market goods needed with the shift from subsistence to cash cropping.

The relatively new category of 'irrigator' is invoked as male and prestigious. 'Harvester', conversely, is feminized labor, performed to a large degree by Kurdish migrant workers from the north (importantly intersecting gender with perceived ethnic hierarchies). Masculinity and femininity, and the very notions of 'difference' between men and women, are thus rearticulated and sedimented in ways that reflect (and produce) the new irrigation economy. 'Women' and femininity take on a new meaning in terms of work obligations to the family as field laborers for the cotton harvest. 'Men' and masculinity, similarly, take on a new meaning in terms of 'he who is able to engage in prestigious work as irrigator, or who can control nature and manage water to produce crops and family income'. Articulated in relation to new irrigated economies and ecologies, 'differences' between male and female are thus cited, maintained, and naturalized. It is precisely through this compulsory insistence on difference, that the very terms and meanings of gender come to matter at all.

There are also interesting parallels between the positive associations and prestige of 'irrigators' as 'life givers' for crop production and associations with reproduction in Turkish cosmology as interpreted by Delaney (1991). As Delaney argues, certain aspects of reproductive cosmology in Turkish village society ascribe active roles to men (as givers of life) and passive roles to women (as carriers or as those who harvest the products of the men's seed). With both irrigation and certain reproductive cosmologies, gender difference is cited in relation to 'nature', associating masculinity with control and determining influences over nature, in contrast to the passive acceptance and nurturing associated with femininity. As Delaney explains, "different seeds can grow in a field; what actually grows is defined by what is sown", implying that men determine a child's identity (or, in this case, the crops grown), and that women serve only to nurture and 
grow the child, with the "climate of her body as a generalized medium of nature, like soil, which any woman can provide" (page 32). In the case of new irrigation agroecologies, both women and landless sharecroppers appear to take on a passive (and substitutable) feminized role, growing and carrying to term crops that have been determined and established by male landowners in the region (as noted, in sharecropping arrangements the landowner determines the crops grown, purchases seeds and inputs, and maintains control over irrigation resources through participation in water user groups, while sharecroppers provide labor, often moving to different plots year after year). These gendered associations clearly undergird important power hierarchies in the region, providing some explanation for the response given by some men that the most prestigious form of work possible is 'to work one's own land', which is considered to be preferable to undertaking such a feminized role on behalf of another.

Returning to discussions in feminist political ecology I argue that analysis of gender environment relations should not be restricted to describing which environmental uses and knowledges are understood as masculine and feminine. In this context it is through the specific practices associated with water use and management that gender comes to matter at all. The difference is subtle. Whereas the former approach to gender allows us to consider the effects of irrigation as a male task, the latter invites us to consider how it is that 'male' or 'female' are in part defined and understood in relation to water use and management. Attention to citationality, or the practices that repeatedly invoke and cite difference, allows us to understand that gender difference appears fixed and stable in part in relation to water uses and management practices. Water uses (who irrigates) and management practices (who participates in management institutions) are examples of the daily material practices through which the idea(I)s of sex difference, or gender, come to make sense and hold meaning. In southeastern Turkey, there would be no justification for disassociating the meanings of 'men' and 'women' from water uses and management practices that increasingly have such importance in the daily lives and material conditions of residents. In this context, water-related practices constitute an increasingly important arena in which gender and other important notions of social difference are renegotiated, rearticulated, or contested.

\section{CONCLUSIONS}

To insist on the association between gender and environment in this manner is to do three things. First, it is to argue that there is no necessary relation between gender and environment, but that this relation is always mediated through specific uses and outcomes: for example, in this case, through labor practices associated with cotton as the predominant emergent crop. Second, it is also to situate gender clearly in context: to understand gender in relation to specific material practices that give meaning to notions and ideals of difference. This is consistent with the idea that analyses of gender should be situated in place, with respect to particular geographies, recognizing too that place cannot and should not be separated from natural environments, interpreted broadly. This framework implies gender studies should be grounded historically, geographically, and practically - in relation to specific practices that hold importance for daily lives, work, and social relations. As gender is necessarily articulated through and in relation to 
race, class, religion, or location, environmental uses or conditions may also be central. Third, to insist on the gender and environment association is to reveal that material discursive geographies are inseparable. Although some authors have critiqued the overfocus of poststructuralist accounts on representation, without dealing with materialist practices or livelihoods (see the discussion in Moeckli and Braun, 2001), I have focused on gender and environment in a way that refuses any possibility of analytical or empirical separation.

Butler's idea of citationality is frequently invoked as one that holds political possibility. (34) Because meaning is never fixed, and is always unstable, this implies that meaning can change over time, suggesting that ideals of appropriate masculinity, femininity, or sexuality shift across time and space. I argue that, although the transition to irrigation appears to sediment and fix the very ideals of gender difference, ethnic difference, or the relative divide between landowners and landless farmers, this is not a necessary outcome. Alternative citations are possible that would essentially (re)inscribe the meanings associated with these differences. This potential implies that there are alternative water-use and management possibilities that might be more equitable, and accordingly which might improve situations for many residents of the plain. The nagging issue of why, in so many different contexts, citations with respect to irrigation consistently serve to reinstate common power differentials remains. ${ }^{(35)}$ As planners hope to create more opportunities for social equity in the GAP region and elsewhere, possibilities for alternative institutions or environments that upset rather than entrench existing social differentials should be explicitly considered.

I noted that the Turkish government is seeking to promote opportunities for women throughout the GAP region. The program that has largely become synonymous with their efforts to promote gender equity is a network of community centers, called ÇATOM. With these centers, planners are attempting to achieve greater equity by creating spaces that focus on women, offering coursework and associational opportunities for women. ${ }^{(36)}$ With the recognition that gender and irrigation changes are fundamentally linked, it becomes apparent that there are other spatial changes - such as those associated with agroenvironmental and landscape changes underway with irrigation that alter, invoke, and (re)inscribe gender - with considerable effects for the situation and relative status of men and women. Recognition of the ways that 'gender differences' are inscribed and articulated in relation to these environmental changes would be great progress over the current approach to 'women' that separates women from men, and attempts to detach 'social' interactions from agro-environmental transformations. Further, the activities of the centers in part serve to reinforce the very notion of gender difference, teaching women sewing, embroidery, and child welfare rather than agricultural techniques, money management, or other skills (compare Ertürk, 1995).

With the new irrigated landscape, categories of gender, ethnicity, or wealth make sense and hold meaning only in relation to current and evolving environmental and material conditions. As such, irrigation not only determines new agricultural possibilities of the region but also becomes central to the very ideals and lived experiences of social difference: Kurd or Arab; landed or landless farmers; and men or women. This suggests that state planners, and gender analysts, might take environmental conditions and 
landscape changes more seriously in attempting to understand, and especially to counter, profound social inequalities. It also suggests that the very terms and categories of gender 'difference' need to be cited in different ways to avoid replicating familiar patterns of inequality. The verb 'to engender' commonly means 'to bring into existence', 'to give rise to'. To date, feminist political ecologists and others have demonstrated the need to consider gender in analyses of environmental change. The possibility exists that we might also more fruitfully investigate how changing nature - society relations and conditions serve to engender the very categories of social difference, including gender. 


\section{AKNOWLEDGEMENTS}

Support for this research was provided by the MacArthur Program on Global Change, Sustainability, and Justice at the University of Minnesota, the American Research Institute in Turkey, and the Jacob K Javits program of the US Department of Education. I would like to thank Nurcan Atalan, who served as assistant for much of the fieldwork for this project, Joel Wainwright, Leyla Neyzi, Eric Sheppard, Mary Thomas, Cindi Katz, two anonymous reviewers, and a number of other readers who contributed to refining this paper in various ways.

\section{Endnotes}

(1) It is worth noting that the recent volume Fragments of Culture edited by Kandiyoti and Saktanber (2002) deals precisely with politics of the everyday and changing patterns of social differentiation in Turkey. The arguments presented here contribute to such a project, and are especially apposite as that volume deals exclusively with urban, suburban, and diasporic contexts. In the volume no effort is made to consider the rural or agrarian aspects of these questions beyond Özyeğin's (2002) chapter on rural ^ urban encounters among newly settled migrants in Ankara - similar to the framing undertaken in her book on doorkeepers and squatter settlers in the capital city (2001).

(2) GAP is the Turkish acronym for 'Southeastern Anatolia Project', Güneydoğ Anadolu Projesi.

(3) I understand the difficulty of characterizing populations as either 'Arab' or 'Kurdish'. Nonethe-less, I use these categorizations at different points because residents themselves generally speak Arabic or Kurdish as their natal language, and most often refer to themselves as 'Arap' or 'Kürt', though many undoubtedly understand themselves, pluralistically, as also Türk (Turkish) or Urfal|

(from the city of Urfa) for example. In over sixty open-ended interviews, only one villager pro- claimed: 'We are Turkish'. More commonly, villagers considered themselves as Kurdish or Arab (often describing their cultural and linguistic attributes along these lines) and as part of the Turkish vatandaş (nation) (field notes based on research carried out in Ankara and in the province of Şanl|urfa, May -November 2001).

(4) Whereas in the past, irrigation water could only be accessed by pumping groundwater, the new irrigation system delivers water via canalet, an above-ground network of cement structures that deliver water, primarily using gravity.

(5) It is important to note that these estimates were for the Southeastern Anatolia region as a whole and not only for the Harran plain. However, as the plain is a pilot irrigation area, the emergent cropping pattern there is significant as an indicator for the entire region. Based on initial irrigation adaptation, GAP planners have since revised estimates, noting that cotton may make up closer to $45 \%$ of the cropping pattern after full implementation of the irrigation works.

(6) Cotton, notorious as both a labor-intensive and an input-intensive crop, has become the preferred crop for a variety of reasons, including state subsidies for each kilo produced and for cotton-related pesticides. Additionally, farmers are relatively familiar with cotton production as many residents of the plain used to travel to the nearby cotton-growing region of Adana, Çurkova, to work as irrigators or cotton harvesters.

(7) There have been several attempts at land reform in the southeast region. For the most part, such efforts have failed. The constitutional court eventually annulled the most recent reform of the 1970s on the grounds that there was inadequate parliamentary debate on this issue before the law was passed. Some people who had recently received land title later lost those lands. At present, similar gaps on landholdings encourage some to put holdings in others' names, including female relatives.

(8) This is a potentially contestable proposition given the context in southeast Turkey. In contrast to a 
number of works that argue for women's participation in irrigation-management institutions and for women's separate land title to further gender-equity concerns (for example, Agarwal, 1994; 2001; Zwarteveen, 1995), it is clear that women often assert identity and wealth as part of the household, and as part of the larger extended familiar lineages associated with the aşiret system (see footnote 15). As Kandiyoti (1988) similarly discusses with respect to differences between Turkish and sub-Saharan African contexts, although it may be common in some contexts for women to maximize economic autonomy as individuals, women in Turkey may be more invested in relationships with their husbands and sons to ensure their protection and security (see White, 1994, pages 60-61). Given this, it may be problematic to argue for women's land entitlements as wholly separate from the family unit.

(9) I use the term 'water user groups' although the translation of sulama birliği is literally 'irrigation unions' or 'associations'.

(10) I use single quotes throughout to indicate that a particular quote was not tape-recorded or directly transcribed but was written from memory after the interviews.

(11) If we total the number of sheep and goats that survey respondents reported owning ten years ago (approximately 6000) and compare this estimate with current holdings (approximately 700) it is clear there has been a significant decline in small-animal herding in the plain (many people are replacing herds of sheep and goats with one or two cows for household milk needs). For landless families there was about a $90 \%$ decline in numbers of sheep and goats, comparable to the overall decline for survey respondents as a whole (88\%). However, this change is likely to be more significant for landless families as they may rely more heavily on herding, and do not have the option of altering crop strategies or allowing grazing on croplands as needed.

(12) Although I do not provide details, the issue of vegetable plots also adds a dimension to ways that water uses are gender differentiated. Several women complained that, because the irrigation schedule caters only to cotton production, pepper and vegetable production (largely women's crops) stops nearly a month earlier than it would if irrigation water continued to be available. Women often dry the pepper for home uses, or sell it as |sot (spicy pepper flakes). This is consistent with many other studies which have found that women's crops are often not prioritized for irrigation delivery (Ahmed, 1999; Zwarteveen, 1995).

(13) Both Kurmanji and ZaZa are spoken among seasonal workers, with Kurmanji as the dominant dialect of Kurdish spoken by permanent residents of the plain.

(14) There are commonly known to be seven major aşirets in the Southeastern Anatolia region, referring to lineage affiliations that have an important role for social relations (for example, marriage often follows aşiret lines) (Doğanay, 1997). The common definition in this context refers to extended families, going back seven generations. State planners also commonly refer to this as a 'tribal' social structure. (15) Interestingly, only $17 \%$ of landed survey respondents identified having participated in farmer education activities, compared with $24 \%$ of landless respondents, indicating that perhaps landless farmers are being targeted by farmer outreach efforts. Both of these numbers are fairly low, however. In our survey $83 \%$ of respondents also indicated that insufficient farmers' education is a problem in the plain and over two thirds of rural residents noted that they have never attended an irrigation meeting or training session.

(16) Similar processes are described by Katz (1991) with respect to family labor balances, cotton production, and shifts towards capitalist production in the Sudan. She writes, "'This transformation, resisted by many, propelled socioeconomic differentiation, exacerbating previously existing differences between households' earnings and assets as it created new ones" (page 492). Just as she notes that these changes were inscribed on the landscape with newly built brick homes and the acquisition of trucks, the landscape in the Harran plain also reflects new irrigation-related wealth. Many residents similarly have purchased cars, and are replacing adobe houses with cement structures, resulting in markedly different social geographies and built environments.

(17) The issue of differences between women according to age and generation is also noted by others, and has important consequences for any evaluation of power and labor balances. As White (1994) describes, the ability to command daughter-in-laws' labor later in life contributes significantly to a cycle in 
which women themselves are invested in patriarchy. See footnote (34) for a discussion of related traditions of patrilocality and linked preference for sons.

(18) With respect to cotton production in the Ivory Coast, Watts and Bassett (1985) argue that the state in that context extracts resources from the rural sector in order to subsidize expansion of the industrial sector. Given that textiles are a primary industry in Turkey, similar arguments could be made for the Turkish context.

(19) I use the term 'bride price' although the practice is also often referred to as 'bride wealth'. I prefer 'bride price' so as not to confuse the practice with çeyiz, used to refer to a bride's Trousseau - including handicrafts and other items for the home that a bride prepares for her

marriage.

(20) The verb 'almak' does not exclusively relate to market purchase. However, many discussions around bride price and marriage involved direct reference to the increasing cost of obtaining a bride, and often men noted that they would directly take the earnings from the cotton harvest to purchase a wife for themselves or for their sons.

(21) White (1994) discusses the seeming contradiction that although many girls do not want to marry they do so for fear of being socially ostracized and in order to obtain the status that comes with becoming a mother and establishing their own household. Several young women made statements that confirmed this idea, noting that, although they may prefer not to get married, they know that if they do not marry by their early to mid-twenties they will face difficulties with their family and community.

(22) In her discussion of marriage, White (1994) also argues that expectations for brides are strongly linked to labor requirements. In her anthropological study of Istanbul, she writes that often in-laws will ensure that a new bride is far away from her family, using spatial separation between her old and new family to avoid conflicts over access to her labor.

(23) It would be difficult to speculate how, if at all, women themselves might benefit from increasing bride price. It is clear that families are attentive to the issue of price, often comparing how much a young girl might fetch as a bride (for example, if one is looking particularly beautiful, the comments might follow related to what sort of price she should expect), and with many young women expressing that their father is likely to take any offer that might come along, especially in times of difficulty.

(24) Even in very rich families, hired laborers will not be employed for household work and child rearing. When I asked one rich wife why this is the case she said that it would be shameful if she did not clean her own house and care for her own children, suggesting strong associations between being a respected wife and mother and engaging in domestic labor.

(25) In response to our survey the strong majority of respondents suggested that men make financial decisions, with 97 respondents (72\%) noting that fathers or husbands make financial decisions alone, versus $15 \%$ who noted that men and women together make financial decisions, and $6 \%$ who noted that women alone make decisions about how to spend money. This is corroborated by results presented in table 1 , where a majority of respondents noted in response to a different question that men primarily make important household decisions.

(26) Similar narratives circulate about resettled communities near dam sites that were compensated for lost land and houses. In some cases, decisionmakers are said to have spent money in short periods of time, gambling or spending lavishly for fun, leaving families with little over the long term.

(27) With respect to education it is interesting to note that, even with obligatory schooling through middle school (eight years of school is mandatory by law), $38 \%$ of respondents said girls should go only to primary school (only the first five years of schooling). As an example of the gender gap with respect to education, 99 out of 124 respondents said that boys should study `as long as they are

able' or through 'university', whereas only 55 respondents provided this answer for girls. When asked why it is that girls do not study, a number of reasons were given by respondents, including the following, listed in order of frequency of mention: social or family expectations (71\%); it is inappropriate for girls to be in 
school (for example, religious reasons, or because of the mixed- sex classroom, noted by 51 percent of respondents); work requirements at home or in the fields (noted by $43 \%$ of respondents); there is little or no benefit to sending girls to school (especially as they will leave once married, $24 \%$ ); and school is more difficult for girls $(7 \%)$.

(28) Some treatment of this issue is provided in work by Moore, Schroeder, and Carney. Moore (1996) focuses on gender expectations in relation to wage labor and differentiated responsibility for land management, and Schroeder (1999) considers how it is that international nongovernmental attention to gender and to women's status conditions environmental change in key ways. As Schroeder details, development agencies focus on gender ${ }^{\wedge}$ environment connections in particular ways, leading planners to assume women's participation in various environmental programs. The example of the Jahaly Pacharr irrigation project described by Carney (1993) is also a case where

planners viewed the project as an opportunity to implement gender-equity goals by making women primary beneficiaries. To varying degrees all of these cases could be viewed as examples whereby gender discourses and practices were key to conditioning particular natures and landscapes.

(29) Kemalist ideals with respect to gender relations and women's status are described at length by a number of works (for example, Arat, 1999; Kandiyoti, 1991). In brief, Mustafa Kemal Atatürk is often attributed with having paid a great deal of attention to women's status and situation, promoting universal education, women's entry into the labor force, and gender equity in legal and institutional terms (although the Civil Code established during the early years of the Republic fell short of establishing true gender equity - for instance, encoding differential rights for men and women with respect to marriage and divorce).

(30) Given this emphasis a useful way to describe this approach might be with the phrase 'ecologies of social difference', highlighting key operations of social difference as they articulate with ecological change and features. Some key questions that would be central to such an approach include: how are categories and associations of difference invoked and maintained in relation to environments and resource conditions? How are categories and processes of sociopolitical difference importantly reworked in relation to environmental changes? These questions make clear how such an approach differs subtly, yet importantly, from other approaches.

(31) Although I do not discuss sexuality explicitly, it is critical to note that Butler's theory of performativity links naturalized sex difference to heteronormativity. In her theorization the reason why bodies are materialized as sexed is linked to the 'heterosexual matrix'. The treatment of gender in the Turkish context is certainly linked to heterosexuality as part of a suite of regulatory practices that materialize gender difference, although I do not detail these aspects here. I would also add, consistent with theorizations provided by Weeks (1998) and others, that economy and labor are also powerful normative orderings that are served by the production of gender ${ }^{\wedge}$ sex.

(32) Weeks (1998) attempts to develop a theory of feminist subjectivity through a notion of feminist standpoint. This work shares certain elements of Butler's theory of performativity (for example, evading familiar traps of free will verses determinism), but also deviates from her work on the grounds that Butler does not adequately account for what compels us to 'do' gender. Weeks argues that Butler does not adequately connect processes of subjectification to larger institutional frameworks and sociopolitical processes (page 128). She also argues that her own notion of feminist standpoint provides an "improved account of both the regime of power and its effects" (page 128). Part of my aim with this paper is precisely to put Butler's theory of performativity to work in ways that "situate these compulsory discursive practices within a socioeconomic matrix" (Weeks, page 129), in this case, emphasizing socioeconomic and political aspects of environmental change. Although Weeks is also attentive to the context in which gender is performed and constituted, here I emphasize the spatial processes that force dynamism and change with respect to gender practices.

(33) The system of patrilocality is largely responsible for the preference for sons, and the status for women who bear sons, as care of elder villagers is secured only by having sons who will marry and remain in the village. A woman also may more easily accept difficult work requirements of her in-laws knowing that, when her sons marry, she will then be able to enjoy and manage her daughter-in-law's 
labor. I was also informed of several occasions where mothers persuaded sons to marry multiple times in order to have more assistance with household needs. In one case, one son with two mothers insisted he marry twice so they could each have their own daughter-in-law who

would care for them (field notes based on research in the province of Şanl|urfa May-November 2001).

(34) Other theorists, including Weeks (1998), argue that labor practices in particular can hold enabling as well as constraining potential. She thus describes women's work in particular as "a site where alternatives can be constructed" (page 7), holding particular potential among a suite of other practices. This framework is consistent with my argument here, as gendered experiences of environmental change and management are linked to labor and other material practices [see Agarwal (1988) or Secor (2003) for a discussion of gender performativity and work in Istanbul].

(35) This general tension exposes a key limitation of contemporary gender theory. Although there is widespread insistence that gender difference is neither natural nor given, the commonality of gender hierarchies, and difficulties with respect to upsetting these hierarchies, continues to pose a theoretical challenge. This idea that gender is unfixed but also persistent and consistent in terms of hierarchical social relations is consistent with Butler's idea of gender performativity as regulatory practice. As she forcefully argues, performativity implies not that one has a choice, but rather that all such practices are compulsory or regulatory.

(36) In another paper (Harris and Atalan, 2004), we consider the importance and effects of ÇCATOM centers for state gender - equity goals. 


\section{BIBLIOGRAPHY}

Agarwal B, 1986, "Women, poverty, and agricultural growth in India" Journal of Peasant Studies 13(4) 165 - 220

Agarwal B, 1988, "Neither sustenance nor sustainability", in Structures of Patriarchy: State, Community, and Household in Modernising Asia Ed. B Agarwal (Kali for Women, New Delhi) pp 83 - 120

Agarwal B,1994 A Field of One's Own:Gender and Land Rights in South Asia (Cambridge University Press, Cambridge)

Agarwal B, 2001, "Participatory exclusions, community forestry, and gender: an analysis for South Asia and a conceptual framework" World Development 291623 - 1648

Ahmed S, 1999, "Changing gender roles in irrigation management: Sadguru's lift irrigation cooperatives" Economic and Political Weekly 343596 - 3607

Arat Z, 1999 Deconstructing Images of the Turkish Woman (Palgrave, Hants)

Basnet K, 1992 Beyond the Chadar and the Chardiwari:Women in the Irrigated Areas of Punjab (IIMI, Lahore)

Butler J, 1993 Bodies that Matter: On the Discursive Limits of 'Sex' (Routledge, New York)

Çarkoğlu A, Eder M, 1998, "The Southeast Anatolia Development Project: part 2" cidc Insight:Turkey August, 113 - 120

Carney J, 1993, "Struggles over crop rights and labour within contract farming households in a Gambian irrigated rice project" Journal of Peasant Studies 15329 - 348

Carney J, 1996, "Converting the wetlands, engendering the environment: the intersection of gender with agrarian change in the Gambia" Liberation Ecologies Eds $R$ Peet, M Watts (Routledge, London) pp 165 - 187

Carney J,Watts M,1991,"Disciplining women? Rice, mechanization and the evolution of Mandinka gender relations in Senegambia" Signs 16651 - 681

Deere C D, Leon M (Eds), 1987 Rural Women and State Policy: Feminist Perspectives on Latin American Agricultural Development (Westview Press, Boulder, CO)

Delaney C, 1991The Seed and the Soil: Gender and Cosmology inTurkishVillage Society (University of California Press, Berkeley, CA)

Doğanay F, 1997 Sosyal ve Kulturel Donuşme Sureçinde Harran Ovasi ve GAPUygulamas| [Harran Plain in the process of social and cultural changes and the implementation of GAP], March (Sosyal Secktorler ve Koordinasyon Genel Mudurlugu [Gender Manager for Social Sectoral Coordination], Adana)

Durakbaşa A, Cindoğlu D, 2002, "Encounters at the counter: gender and the shopping 
experience", in Fragments ofCulture:The Everyday ofModernTurkey

EdsDKandiyoti,ASaktanber (Rutgers University Press, New Brunswick, NJ) pp 73 - 89

Ertürk Y, 1995, "Rural women and modernization in southeastern Anatolia", inWomen in Modern Turkish Society Ed. S Tekeli (Zed Books, London) pp 141 - 152

Gupta A, 1998 Postcolonial Developments: Agriculture in the Making of Modern India (Duke University Press, Durham, NC)

Harris L, 2002, "Water and conflict geographies of the Southeastern Anatolia Project" Society and Natural Resources 15743 - 759

Harris L, 2005, "Negotiating inequalities: democracy, gender, and politics of difference in water user groups of Southeastern Turkey", in Environmentalism in Turkey: Between Democracy and Development? Eds F Adaman, M Arsel (Ashgate, Aldershot, Hants) pp $185-200$

Harris L, Atalan N, 2004, "Developing women's spaces: evaluation of the importance of sex segregated spaces for gender and development goals in southeastern Turkey" Kadn/Woman 2000 3(2) 17 - 46

Harris L, Karahan Kara Z, 2001, "Survey of 125 rural households conducted in 11 villages of the Harran Plain, November 2001", available from the author

Kabeer N, 1994 Reversed Realities: Gender Hierarchies in Development Thought (Verso, London)

Kandiyoti D, 1988, "Bargaining with patriarchy" Gender and Society 2274 - 290

Kandiyoti D, 1990, "Women and rural development policies: the changing agenda" Development and Change 21(1) 5 - 22

Kandiyoti D, 1991Women, Islam, and the State (Temple University Press, Philadelphia, PA)

Kandiyoti D, Saktanber A, 2002 Fragments of Culture: The Everyday of Modern Turkey (Rutgers University Press, New Brunswick, NJ)

Katz C, 1991, "Sow what you know: the struggle for social reproduction in rural Sudan"Annals of the Association of American Geographers 81488 - 514

Katz C, 1998, "Whose nature, whose culture?: Private productions of space and the 'preservation' of nature", in Remaking Reality: Nature at the Millenium Eds B Braun, $N$ Castree (Routledge, London) pp 46 - 63

Moeckli J, Braun B, 2001, "Gendered natures: feminism, politics, and social nature", in Social Nature: Theory, Practice, and Politics Eds B Braun, N Castree (Blackwell, Oxford) pp 112 - 132

Moore D, 1996, "Marxism, culture, and political ecology: environmental struggles in Zimbabwe's eastern Highlands", in Liberation Ecologies Eds R Peet, M Watts (Routledge, London) pp 125 - 147 
Nash C, 2000, "Performativity in practice: some recent work in cultural geography" Progress in Human Geography 24653 - 664

Özyeğin G, 2001Untidy Gender: Domestic Service inTurkey (Temple University Press, Philadelphia, PA)

Özyeğin G, 2002, "The doorkeeper, the maid, and the tenant: troubling encounters in the Turkish urban landscape", in Fragments of Culture: The Everyday of Modern Turkey Eds D Kandiyoli, A Saktanber (Rutgers University Press, New Brunswick, NJ) pp 43 72

Pangare 1998 Gender Issues in Watershed Development and Management in India Agricultural Research and Extension Network, Overseas Development Institute, London

Raynolds L, 1991, "Women and agriculture in the Third World: a review and critique", in Towards a New Political Economy of Agriculture Eds W H Friedland, L Busch, F H Buttel, A P Rudy (Westview Press, Boulder, CO) pp 339 - 363

Rocheleau D, Thomas-Slayter B, Wangari E, 1996 Feminist Political Ecology: Global Issues and Local Experiences (Routledge, New York)

Schroeder R, 1999 Shady Practices: Agroforestry, Gender Politics in the Gambia (University of California Press, Berkeley, CA)

Secor A, 2003, "Belaboring gender: the spatial practice of work and the politics of 'making do' in Istanbul" Environment and Planning A 352209 - 2227

Thomas M, 2004, "Pleasure and propriety: teen girls and the practice of straight space" Environment and Planning D: Society and Space 22773 - 789

Ünver I H O, 1997, "Southeastern Anatolia Project (GAP) "Water Resources Development 13453 - 483

Watts M, Bassett T, 1985, "Crisis and change in African agriculture: a comparative study of the Ivory Coast and Nigeria" African Studies Review 28(4) 3 - 27

Weeks K, 1998 Constituting Feminist Subjects (Cornell University Press, Ithaca, NY)

White J,1994 Money Makes Us Relatives: Women's Labor in Urban Turkey (University of Texas Press, Austin, TX)

Zwarteveen M, 1995 Linking Women to the Main Canal: Gender and Irrigation Management (International Institute for Environment and Development, London) 